\title{
PXN wt Allele
}

National Cancer Institute

\section{Source}

National Cancer Institute. PXN wt Allele. NCI Thesaurus. Code C104207.

Human PXN wild-type allele is located in the vicinity of 12 q24.31 and is approximately 55

$\mathrm{kb}$ in length. This allele, which encodes paxillin protein, is involved in focal adhesions,

cytoskeletal structure and integrin-mediated signaling. 